Gut, 1986, 27, 652-658

\title{
Antral release of gastrin and somatostatin in duodenal ulcer and control subjects
}

\author{
R F HARTY, D G MAICO AND J E McGUIGAN \\ From the Division of Gastroenterology, Department of Medicine, University of Florida College of Medicine, \\ Gainesville, Florida, USA.
}

SUMMARY Organ culture was used to compare gastrin and somatostatin release from cultured antral mucosa obtained from duodenal ulcer and non-ulcer (control) subjects. In response to dibutyryl cyclic AMP (DBCAMP) cultured antral mucosal explants from patients with a history of duodenal ulcer released a greater proportion of antral gastrin into the medium than did antral mucosal explants from non-ulcer subjects. Somatostatin release from antral mucosa from duodenal ulcer patients was substantially less than somatostatin released by antral explants from non-ulcer subjects. In the non-ulcer subjects there was a direct positive correlation between the amounts of antral somatostatin and gastrin released into the culture medium $(r=0 \cdot 64,<p 0 \cdot 01)$. In the duodenal ulcer patients, however, there was no correlation between gastrin release and somatostatin release from antral mucosa $(r=0.09 ; p>0.2)$. Results of these studies identify enhanced gastrin release in response to stimulation and decreased release of somatostatin from antral mucosa of duodenal ulcer patients. These alterations in paracrine relationships of antral somatostatin and gastrin in duodenal ulcer subjects may contribute, at least in part, to the pathogenesis of duodenal ulcer disease.

The pathogenesis of duodenal ulcer disease is complex and is believed to involve interactions of multiple factors. ${ }^{1-4}$ In vivo human studies designed to define differences between duodenal ulcer patients and non-ulcer subjects have dealt principally with comparisons of gastric acid secretory rates, ${ }^{5-7}$ clearance of acid from the stomach ${ }^{8}$ and duodenum ${ }^{9}$ and acid mediated feedback inhibition of antral gastrin release. ${ }^{10}$ Parietal cell function has been examined to determine acid secretory capacity and responsiveness to exogenously administered stimuli $^{11}$ and to endogenously released gastrin. ${ }^{12}$

Somatostatin has been shown to possess the capacity to inhibit both gastrin release and gastric acid secretion. Somatostatin is present in large concentrations in antral mucosa in cells intimately proximate to gastrin-containing and -releasing cells and is also released into the circulation. It is as yet uncertain to what extent gastrin release and gastric acid secretion are regulated by local (paracrine)

Address for correspondence: Richard F Harty, MD, Division of Gastroenterology, Department of Internal Medicine, University of Nebraska Medical Center, 42nd Street and Dewey Avenue, Omaha, Nebraska 68105. USA.

Received for publication 3 October 1985. and/or systemic effects of somatostatin. ${ }^{13}$ Recent studies have suggested that alterations in local actions (paracrine functions) of somatostatin and gastrin in the antral mucosa may, at least in part, contribute to enhanced gastrin release and increases in gastric acid secretion in duodenal ulcer. ${ }^{14} 15$

The present study was directed to examine and compare potential paracrine relationships between gastrin and somatostatin in antral mucosa of duodenal ulcer and non-ulcer subjects. In vitro organ culture $^{16-18}$ of antral mucosa was utilised as an experimental model for the study of similarities and differences between duodenal ulcer and non-ulcer subjects in antral gastrin and somatostatin release during short term culture.

\section{Methods}

SUBJECTS

The volunteer subjects were nine men with chronic duodenal ulcer disease and nine healthy men without history of peptic ulcer disease. The mean age of the duodenal ulcer subjects was 51 years (range 23-64 years) and the mean age of control individuals was 39 years (range 28-61 years). Individuals with 
chronic duodenal ulcer disease had the diagnosis established endoscopically during previous evaluation of recurrent symptomatic disease, At the time of study no patient with chronic duodenal ulcer disease had endoscopic evidence of active duodenal or gastric ulcer. None of the study subjects had serious accompanying medical illnesses, previous gastric surgery, or evidence of gastric outlet obstruction. Fasting serum gastrin concentrations were normal $(<150 \mathrm{pg} / \mathrm{ml})$ in all ulcer and non-ulcer subjects. All oral medications were discontinued three days before oesophagogastroduodenoscopy.

Complete oesophagogastroduodenoscopy examination was done in all subjects before obtaining antral tissue. Individuals with endoscopic evidence of active duodenal or gastric ulcer, duodenitis or gastritis were excluded from the study. All subjects volunteered for the study and gave written informed consent. The study was approved by The Human Research Committee of the University of Florida College of Medicine.

ENDOSCOPIC PROCUREMENT OF ANTRAL MUCOSAL EXPLANTS

After overnight fast, subjects underwent oesophagogastroduodenoscopy with an ACMI F-8 end-viewing panendoscope. The posterior pharynx was anesthetised with topical $4 \%$ lidocaine. When required to achieve mild sedation, diazepam was administered intravenously before and during the procedure. Atropine or other anticholinergic medications were not administered. Oral secretions were controlled during the procedure by oropharyngeal suction. Antral mucosal biopsies for use as explants were obtained by use of standard Olympus endoscopic biopsy forceps without central tissue spike. Sixteen to 30 consecutive antral biopsies were obtained from each subject and were transferred immediately to the organ culture system. The majority of antral mucosal specimens were obtained from the immediate prepyloric area along the greater and lesser curvatures. Both duodenal ulcer and non-ulcer subjects tolerated the procedure well, without significant symptoms and/or complications.

ORGAN CULTURE TECHNIQUES AND ANALYTICAL PROCEDURES

A total of 410 antral mucosal biopsies were obtained and cultured as individual antral explants using the organ culture technique previously described. ${ }^{19}$ Antral mucosal explants were cultured in TrowellT8 culture medium (Grand Island Biological Co, Grand Island, NY) to which were added penicillin $(100 \mathrm{U} / \mathrm{ml})$ and streptomycin $(100 \mu \mathrm{g} / \mathrm{ml})$. Explants were incubated for an initial hour of stabilisation after which the culture medium was removed and exchanged with fresh Trowell-T8 culture medium. Culture of the antral explants was continued for an additional six hours after the culture medium exchange. In vitro gastrin release by antral mucosa from duodenal ulcer and control subjects was determined under basal culture conditions and in response to dibutyryl cyclic AMP (DBCAMP; $10 \mathrm{mM}$ ) (Sigma Chemical Co, St Louis, MO). The culture medium was sampled $(10 \mu \mathrm{l})$ at $0 \cdot 5,2,4$, and six hours for determination of gastrin content. Somatostatin content of the medium was measured at the termination of the six hour culture period. Recovery from the media of added gastrin and somatostatin after six hour organ culture was $95 \cdot 2 \pm 1.4$ and $90 \cdot 2 \pm 2 \cdot 1 \%$, respectively. At completion of six hours of culture the explants were weighed promptly, frozen on dry ice and were then maintained at $-20^{\circ} \mathrm{C}$, until peptide hormone extraction. ${ }^{1819}$ Residual tissue sediments were preserved for protein determination. Media and antral tissue gastrin and somatostatin contents were determined by radioimmunoassay. ${ }^{19-21}$ Radioimmunoassay of gastrin and somatostatin showed intraassay coefficients of variation of 5 and $6 \%$ and interassay coefficients of variation of 10 and $12 \%$, respectively. Gastrin and somatostatin release were expressed as nanogram peptide per milligram tissue or per cent of antral explant peptide released into the culture medium. Values were represented as the mean \pm 1 standard error of the mean. Statistical significance was assigned when $p<0 \cdot 05$. Data were analysed by paired and unpaired Student's $t$ test and linear regression analysis.

\section{Results}

GASTRIN CONTENT OF AND RELEASE FROM

CULTURED ANTRAL EXPLANTS

Gastrin contents of antral mucosal specimens from individual subjects and from different subjects in both groups varied considerably: range of antral mucosal gastrin content $0 \cdot 1-29.7 \mathrm{ng} / \mathrm{mg}$ explant (Table 1). The mean gastrin content of antral mucosa from duodenal ulcer patients was $2 \cdot 2 \pm 0 \cdot 4$ and that for the non-ulcer subjects was $6 \cdot 7 \pm 1.9 \mathrm{ng}$ gastrin/mg explant $(p<0 \cdot 05)$. Explant gastrin contents, with basal culture medium alone or in the presence of DBCAMP, did not change during the duration of culture $(p>0 \cdot 1)$.

Despite variability in antral tissue gastrin contents the per cent of antral gastrin released into the medium under basal (control) culture conditions was similar for both non-ulcer and duodenal ulcer subjects: $6.9 \pm 1.0$ and $5 \cdot 8 \pm 1.2 \%$ total gastrin per hour, respectively $(p>0 \cdot 1)$. Dibutryl cyclic AMP (DBCAMP) stimulated gastrin release from antral 
Table 1. Gastrin contents of cultured antral explants

\begin{tabular}{|c|c|c|c|c|c|c|}
\hline \multirow{2}{*}{$\begin{array}{l}\text { Subject } \\
\text { no. }\end{array}$} & \multicolumn{3}{|c|}{ Non-ulcer subjects tissue gastrin content (ng/mg explant) } & \multicolumn{3}{|c|}{ Duodenal ulcer patients tissue gastrin content ( $\mathrm{ng} / \mathrm{mg}$ explant) } \\
\hline & $n^{*}$ & $M e a n \pm S E M$ & Range & $n$ & $M e a n \pm S E M$ & Range \\
\hline 1 & 15 & $9 \cdot 6 \pm 2 \cdot 4$ & $(0 \cdot 8-28 \cdot 8)$ & 15 & $4 \cdot 5 \pm 0 \cdot 4$ & $(2 \cdot 2-7 \cdot 5)$ \\
\hline 2 & 6 & $1 \cdot 5 \pm 0 \cdot 3$ & $(0 \cdot 4-2 \cdot 0)$ & 14 & $3 \cdot 3 \pm 0 \cdot 6$ & $(0 \cdot 4-7 \cdot 3)$ \\
\hline 3 & 8 & $2.4 \pm 0.7$ & $(0 \cdot 5-6 \cdot 2)$ & 7 & $1 \cdot 6 \pm 0 \cdot 3$ & $(1 \cdot 4-4 \cdot 7)$ \\
\hline 4 & 10 & $1 \cdot 2 \pm 0 \cdot 3$ & $(0 \cdot 6-4 \cdot 0)$ & 7 & $1 \cdot 0 \pm 0 \cdot 3$ & $(0 \cdot 1-1 \cdot 6)$ \\
\hline 5 & 7 & $1 \cdot 3 \pm 0 \cdot 5$ & $(0 \cdot 2-3 \cdot 8)$ & 11 & $1 \cdot 9 \pm 0 \cdot 2$ & $(1 \cdot 0-3 \cdot 2)$ \\
\hline 6 & 15 & $15 \cdot 7 \pm 1 \cdot 9$ & $(5 \cdot 0-26 \cdot 5)$ & 11 & $3 \cdot 4 \pm(0 \cdot 4$ & $(1 \cdot 0-4 \cdot 8)$ \\
\hline 7 & 13 & $14 \cdot 8 \pm 1 \cdot 9$ & $(5.9-29.7)$ & 15 & $1 \cdot 0 \pm 0 \cdot 4$ & $(0 \cdot 3-6 \cdot 5)$ \\
\hline 8 & 10 & $9.7 \pm 1.9$ & $(4 \cdot 2-23 \cdot 0)$ & 10 & $1 \cdot 9 \pm 0 \cdot 4$ & $(0 \cdot 4-4 \cdot 8)$ \\
\hline 9 & 10 & $3 \cdot 9 \pm 0 \cdot 5$ & $(0.9-6 \cdot 7)$ & 11 & $1 \cdot 4 \pm 0 \cdot 2$ & $(0 \cdot 3-2 \cdot 1)$ \\
\hline Mean \pm & & $6 \cdot 7 \pm 1 \cdot 9$ & & & $2 \cdot 2 \pm 0 \cdot 4$ & \\
\hline
\end{tabular}

${ }^{*} n$ equals the number of individual antral explants cultured.

explants from both duodenal ulcer and non-ulcer subjects (Table 2). The cumulative proportion of gastrin release stimulated by DBCAMP during the six hour culture was substantially greater in the duodenal ulcer patients than control: gastrin release stimulated by DBCAMP from antral mucosa from duodenal ulcer patients was 2.5 times greater than DBCAMP stimulated gastrin release from antral mucosa of non-duodenal ulcer subjects: $16 \cdot 8 \pm 3 \cdot 3 \mathrm{vs}$ $6 \cdot 5 \pm 1 \cdot 3 \%$ change from basal $(\mathrm{p}<0 \cdot 01)$, respectively (Fig. 1).

\section{ANTRAL SOMATOSTATIN CONTENT}

Antral mucosal explants from duodenal ulcer patients contained less somatostatin (129.8 $\pm 53 \cdot 4$

Table 2 Antral mucosal gastrin release in the presence or absence of dibutyryl cyclic AMP (DBCAMP)

\begin{tabular}{|c|c|c|c|c|}
\hline \multirow[b]{2}{*}{ Patient no. } & \multicolumn{2}{|c|}{$\begin{array}{l}\text { Non-ulcer } \\
\text { subjects and } \\
\text { antral gastrin } \\
\text { released }\end{array}$} & \multicolumn{2}{|c|}{$\begin{array}{l}\text { Duodenal ulcer } \\
\text { patients and } \\
\text { antral gastrin } \\
\text { released }\end{array}$} \\
\hline & Basal & $D B C A M P$ & Basal & $D B C A M P$ \\
\hline 1 & 24.9 & $35 \cdot 8$ & $21 \cdot 4$ & $44 \cdot 4$ \\
\hline 2 & $67 \cdot 3$ & $70 \cdot 3$ & $46 \cdot 5$ & $53 \cdot 8$ \\
\hline 3 & $57 \cdot 5$ & 64.9 & $14 \cdot 7$ & $51 \cdot 5$ \\
\hline 4 & $49 \cdot 8$ & 57.9 & $42 \cdot 2$ & $50 \cdot 3$ \\
\hline 5 & $41 \cdot 6$ & $41 \cdot 2$ & $43 \cdot 7$ & $57 \cdot 1$ \\
\hline 6 & $36 \cdot 2$ & $43 \cdot 1$ & $36 \cdot 9$ & $53 \cdot 2$ \\
\hline 7 & $14 \cdot 8$ & $17 \cdot 0$ & 9.6 & $35 \cdot 3$ \\
\hline 8 & $25 \cdot 8$ & $36 \cdot 3$ & $28 \cdot 1$ & 33.9 \\
\hline 9 & $58 \cdot 1$ & $68 \cdot 4$ & $30 \cdot 0$ & $44 \cdot 8$ \\
\hline $\begin{array}{l}\text { Mean } \pm \text { SEM } \\
\mathrm{p}^{*}\end{array}$ & $41 \cdot 9 \pm 5.9$ & $\begin{array}{l}48 \cdot 3 \pm 6 \cdot 0 \\
0 \cdot 01]\end{array}$ & $\begin{array}{r}34 \cdot 8 \pm 7 \cdot 2 \\
\leq p<\end{array}$ & $0.1 \pm 2 \cdot 7$ \\
\hline
\end{tabular}

${ }^{*} p$ was calculated by paired $t$-test to estimate significance of difference in per cent gastrin release during six hours of culture in the presence or absence (basal) of DBCAMP.

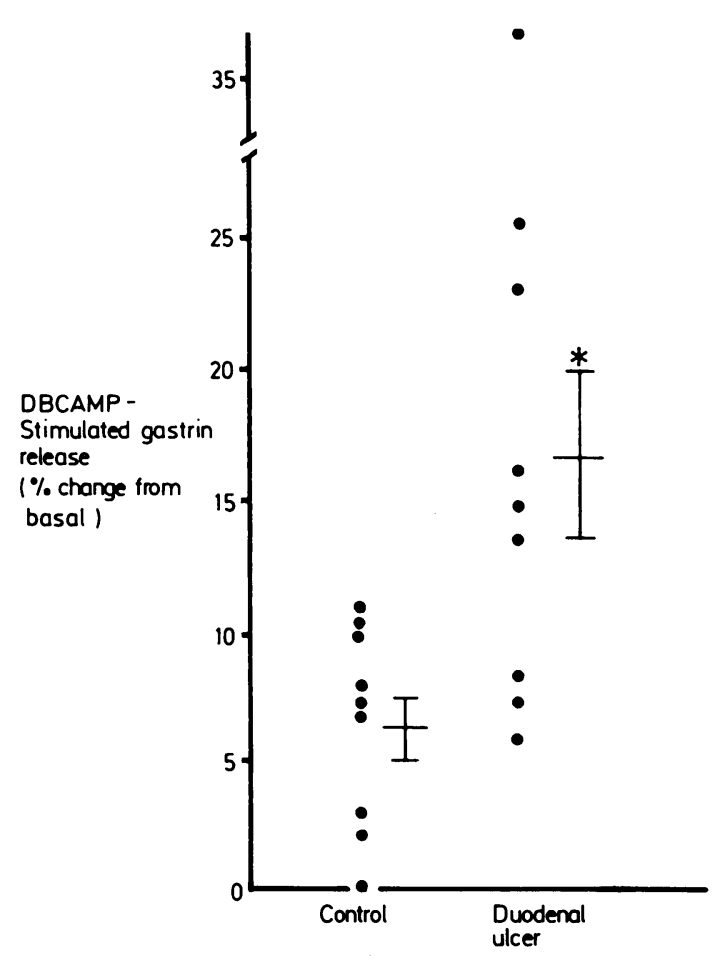

Fig. 1 Dibutyryl cyclic AMP stimulated gastrin release from antral mucosal explants from non-ulcer subjects $(n=9)$ and from duodenal ulcer patients $(n=9)$ is expressed as per cent change from basal (non-stimulated) gastrin release. ${ }^{*} p<0.01$.

$\mathrm{pg} / \mathrm{mg}$ explant) than antral mucosa from the nonulcer subjects $(260 \cdot 5 \pm 56 \cdot 1 \mathrm{pg} / \mathrm{mg}$ explant $)$ $(p<0.03)$. The amounts of antral somatostatin relative to antral gastrin, however, were similar in antral mucosal explants from duodenal ulcer and non-ulcer 
subjects $(5.9$ and $3.9 \%$, respectively). Culture of antral mucosa in the presence of DBCAMP did not alter the mean tissue somatostatin content of antral mucosal explants from the duodenal ulcer patients $(123.9 \pm 42.3 \mathrm{pg} / \mathrm{mg}$ explant, $\mathrm{p}>0 \cdot 1)$ nor from the non-ulcer subjects $(242.2 \pm 52.7 \mathrm{pg} / \mathrm{mg}$ explant, $\mathrm{p}>0 \cdot 1)$.

\section{SOMATOSTATIN RELEASE}

Figure 2 compares somatostatin release from antral mucosal explants from duodenal ulcer and non-ulcer subjects. Antral mucosal explants from duodenal ulcer patients released substantially less somatostatin than antral mucosal explants from non-ulcer subjects: antral mucosa from duodenal ulcer patients released $11.5 \pm 5.8 \%$ compared with $34.9 \pm 5.9 \%$ explant somatostatin for the non-ulcer subjects $(p<0 \cdot 02)$. Addition of DBCAMP to cultures of antral tissue from non-ulcer subjects was associated with substantial increases in somatostatin release into the culture media in five of nine experiments. Analysis of the combined data by paired $t$ test, however, did not show statistically significant stimulation by DBCAMP of somatostatin release from antral mucosal cultures of non-ulcer

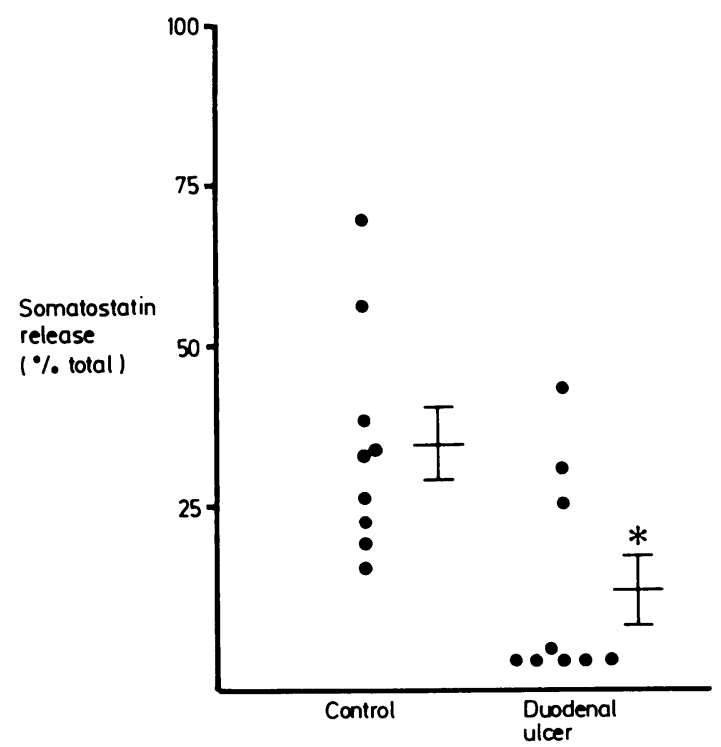

Fig. 2 Comparison of somatostatin release from control and duodenal ulcer antral explants of six hours (basal culture medium). Release of somatostatin from antral mucosal explants of duodenal ulcer patients $(11 \cdot 5 \pm 5 \cdot 8 \%$ total somatostatin) was substantially less than that for antral mucosa of non-duodenal ulcer subjects $(34.9 \pm 5.9 \%$ total somatostatin). ${ }^{*} p<0 \cdot 02$.

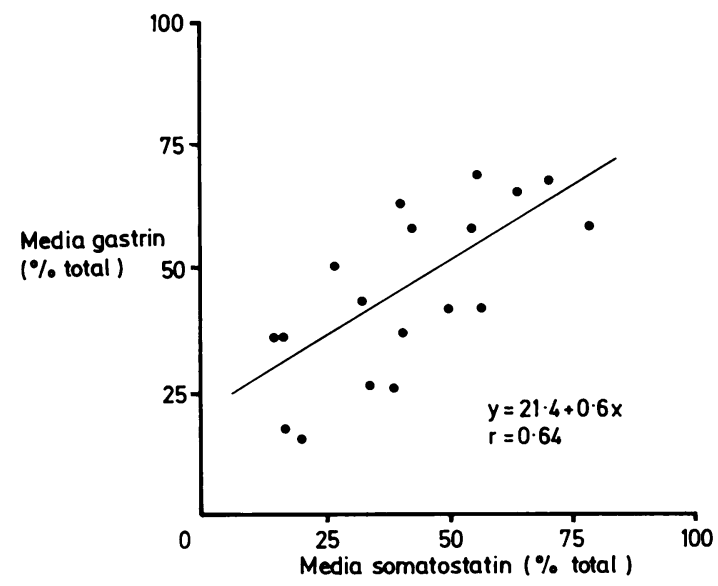

Fig. 3 Positive correlation between release of somatostatin and gastrin from antral explants from non-ulcer subjects. The solid line is the linear progression line. Individual points represent data obtained from cultures of antral mucosal explants from non-ulcer subjects cultured in the presence of basal culture medium and medium containing $D B C A M P$.

subjects. In contrast with these findings, DBCAMP did not affect somatostatin release from antral mucosal explants of any of the nine duodenal ulcer patients.

In the non-ulcer subjects there was a direct $(r=0.64)$ relationship $(p<0.01)$ between the release of antral explant somatostatin and gastrin into the culture medium under basal and stimulated (DBCAMP) conditions (Fig. 3). In contrast, however, with cultures of antral explants of duodenal ulcer patients there was no correlation between antral somatostatin release and antral gastrin release into the culture medium $(r=0 \cdot 09 ; p>0 \cdot 1)$.

\section{Discussion}

Most investigators have found that many, but not all, patients with duodenal ulcer release more gastrin into the circulation in response to a standard protein meal than do non-ulcer subjects. ${ }^{5}{ }^{729}$ Enhanced gastrin release in patients with duodenal ulcer has not been accounted for by increased amounts of gastrin in the antral mucosa and/or greater numbers of antral gastrin cells. ${ }^{22-28}$ Studies examining the gastrin content of antral mucosa of duodenal ulcer patients have yielded variable results, being reported as low, ${ }^{22}$ normal ${ }^{23} 24$ or high $^{24-26}$ in comparison with non-ulcer individuals. In the present study, in order to minimise error because of variations in gastrin distribution in the antral mucosa, large numbers of antral mucosal 
samples (16 to 30 were obtained from each subject and each antral mucosal explant was examined individually. Gastrin release in these studies was expressed as a function of antral gastrin content.

It has been proposed that increased gastrin responsiveness in duodenal ulcer patients may be due, at least in part, to enhanced functional activity of gastrin cells. ${ }^{30}{ }^{31}$ This study represents the first in vitro comparison of functional cellular responsiveness and potential paracrine interrelationships between antral mucosal gastrin and somatostatin of duodenal ulcer and non-ulcer subjects. Previous studies from our laboratory, using rat antral mucosa in organ culture, demonstrated the capacity of cyclic AMP to stimulate gastrin release and provided evidence in support of a role for endogenous cyclic AMP in stimulating release of antral gastrin. ${ }^{32}$ In the present study cultured antral mucosal explants from duodenal ulcer subjects were found to release a larger proportion of antral gastrin into the medium in response to DBCAMP stimulation than did antral mucosal explants from non-ulcer subjects. It is not possible to compare directly these in vitro observations to those results of in vivo human investigations. Nonetheless, these studies define demonstrable differences in gastrin cell responsiveness to stimulation in vitro which may reflect fundamental alterations in gastrin cell responsiveness and/or disturbances in antral paracrine influences on gastrin cells of duodenal ulcer patients.

Somatostatin has been proposed as a locally acting paracrine regulator (inhibitor) of antral mucosal gastrin release. ${ }^{33-35}$ In the present study, somatostatin release from antral mucosa from duodenal ulcer subjects was substantially reduced. Antral mucosa from the duodenal ulcer patients released less than one-third the amount of somatostatin released by antral explants from non-ulcer subjects. In the non-stimulated (basal) state, however, this reduced level of somatostatin release did not affect basal gastrin release from antral mucosa from duodenal ulcer subjects. These findings are contrasted with the significant differences observed in DBCAMP stimulated gastrin release from antral mucosa from duodenal ulcer subjects when compared with control subjects.

These studies support the hypothesis that inhibitory paracrine influences on antral gastrin cells by somatostatin may be disordered in duodenal ulcer, thereby reducing or removing normal somatostatin mediated inhibition of gastrin release. In the nonulcer subjects we found a direct correlation between antral release of somatostatin and gastrin into the culture medium, whereas this correlation was not found with culture of antral mucosa from duodenal ulcer patients (Fig. 3). The direct relationship between antral gastrin release and somatostatin release by antral mucosa in the non-ulcer subjects may represent one limb of a feedback control mechanism, in which release of gastrin may be modulated by released somatostatin through its paracrine action on the $\mathrm{G}$ cell, effecting inhibition of gastrin release. ${ }^{36}$ In normal individuals antral somatostatin containing (D) cells positioned in intimate proximity to gastrin containing and releasing (G) cells may respond to alterations in local environmental concentrations of gastrin. Occupancy of gastrin receptors on the surfaces of somatostatin cells would result in stimulation of somatostatin synthesis and release. Reduced occupancy of these receptor sites by gastrin would reduce somatostatin synthesis and release. In this manner, somatostatin is proposed to serve a local modulating role (suppression) in regulation of further gastrin release. The direct correlation between antral gastrin and somatostatin release observed in the non-ulcer subjects is consistent with this proposed mechanism for somatostatin-gastrin regulation. The lack of a direct relationship between antral mucosal gastrin and somatostatin release, associated with decreased antral mucosal somatostatin release, in the duodenal ulcer patients suggests a defect in this regulatory mechanism. The nature of this defect is as yet not defined. Studies have shown that the number and ratio of antral $G$ and $D$ cells in duodenal ulcer subjects are the same as in control individuals. ${ }^{37}$ Functional differences in D cells of duodenal ulcer subjects may be reflected by a decrease in the number or affinity of gastric receptors on antral mucosal somatostatin cells, a defect in the transmission of gastrin, or access of gastrin, to those receptors, or a defect in the postgastrin receptor responsible for promoting somatostatin synthesis and release. A defect in this proposed paracrine somatostatin-gastrin control mechanism in duodenal ulcer would be expressed by an absolute reduction in somatostatin release, increased gastrin in response to stimulation, and a dissociation between gastrin release and somatostatin release, as identified in this study.

Results of these experiments have shown decreased release of somatostatin as well as increased release of gastrin by antral mucosa of duodenal ulcer subjects: these were associated with an absence of the direct relationship between antral somatostatin and gastrin release found in non-ulcer subjects. These results suggest alterations in paracrine relationships between antral mucosal somatostatin and gastrin in patients with duodenal ulcer, which may contribute to abnormalities in regulatory peptide release in duodenal ulcer. 
Supported in part by Research Grant AM 13711 and Clinical Investigator Award AM 00298 (Dr Harty) from the National Institutes of Health.

\section{References}

1 Grossman MI. Abnormalities of acid secretion in patients with duodenal ulcer. Gastroenterology 1978; 75: 524-6.

2 Rotter JK, Rimoin DL. Peptic ulcer disease - a heterogeneous group of disorders. Gastroenterology 1977; 73: $604-7$.

3 Walsh JH. Pathogenetic role of the gastrins. In: Rehfeld JF, Amdrup E, eds. Gastrins and the vagus. London: Academic Press, Inc, 1979: 181-98.

4 Isenberg JI, Richardson CT, Fordtran JS. Pathogenesis of peptic ulcer. In: Sleisenger MH, Fordtran JS, eds. Gastrointestinal disease: pathophysiology, diagnosis, management. Philadelphia: W B Saunders Co. 1978: 792-806.

5 Fordtran JS, Walsh JH. Gastric acid secretion rate and buffer content of the stomach after eating. Results in normal subjects and in patients with duodenal ulcer. $J$ Clin Invest 1973; 52: 645-57.

6 Wormsley KG, Grossman MI. Maximal histalog test in control subjects and patients with peptic ulcer. Gut 1965; 6: 427-35.

7 Richardson CT, Walsh JH, Hicks MI, Fordtran JS. Studies on the mechanisms of food-stimulated gastric acid secretion in normal subjects. J Clin Invest 1976; 58: 623-31.

8 Malagelada JR, Longstreth GF, Deering TB, Summerskill WH, Go UL. Gastric secretion and emptying after ordinary meals in duodenal ulcer. Gastroenterology 1977; 73: 989-94.

9 Archambault AP, Rovelstad RA, Carlson HC. In situ $\mathrm{pH}$ of duodenal bulb contents in normal and duodenal ulcer subjects. Gastroenterology 1967; 52: 940-7.

10 Walsh JH, Richardson CT, Fordtran JS. pH dependence of acid secretion and gastrin release in normal and ulcer subjects. J Clin Invest 1976; 55: 462-8.

11 Isenberg JI, Grossman MI, Maxwell V, Walsh JH. Increased sensitivity of stimulation of acid secretion by pentagastrin in duodenal ulcer. J Clin Invest 1975; 55: 330-7.

12 Lam SK, Isenberg JI, Grossman MI, Lene WH, Walsh JH. Gastric acid secretion is abnormally sensitive to endogenous gastrin release after peptone test meals in duodenal ulcer patients. J Clin Invest 1980; 65: 555-62.

13 Colturi TJ, Unger RH, Feldman M. Role of circulating somatostatin in regulation of gastric acid secretion, gastrin release and islet cell function: studies in healthy subjects and duodenal ulcer patients. J Clin Invest 1984; 74: 417-23.

14 Sumii K, Fuskushima T, Hirata K, Matsumoto Y, Sanuki E, Tsumaru S, Sumioka M, Miyoshi A, Miyachi Y. Antral gastrin and somatostatin concentrations in peptic ulcer patients. Peptides 1981; 2: 281-3.

15 Konturek SJ. Somatostatin and gastrointestinal secretion and motility. Adv Exp Med Biol 1978; 106: 227-34.
16 Browning TH, Trier JS. Organ culture of mucosal biopsies of human small intestine. J Clin Invest 1969; 48: $1423-32$.

17 Kagnoff MJ, Donaldson RM, Trier JS. Organ culture of rabbit small intestine: prolonged in vitro steady state protein synthesis and secretion and secretory $\operatorname{IgA}$ secretion. Gastroenterology 1972; 63: 541-51.

18 Harty RF, Van der Vijver JC, McGuigan JE. Stimulation of gastrin secretion and synthesis in antral organ culture. J Clin Invest 1977; 60: 51-60.

19 Arimura A, Sato H, Dupont A, et al. Somatostatin: abundance of immunoreactive hormone in rat stomach and pancreas. Science 1975; 189: 1007-9.

20 McGuigan JE, Wolfe MM. Gastrin radioimmunoassay. Clin Chem 1982; 28: 368-73.

21 Wolfe MM, Reel GM, McGuigan JE. Inhibition of gastrin release by secretin is mediated by somatostatin in cultured antral mucosa. J Clin Invest 1983; 72: 1586-93.

22 Barbara L, Biasco G, Salera M, Baldi F, Di Febo C, Miglioli M. Antral $G$ cells and mucosal gastrin concentration in normal subjects and in patients with duodenal ulcer. Adv Exp Med Biol 1978; 106: 97-104.

23 Malstrom J, Stadil F, Rehfeld JF. Gastrins in tissue concentration and component pattern in gastric, duodenal and jejunal mucosa of normal human subjects and patients with duodenal ulcer. Gastroenterology 1976; 70: 697-703.

24 Creutzfeldt W, Creutzfeldt C, Arnold R. Gastrinproducing cells. In: Chey WY, Brooks SP, eds. Endocrinology of the gut. New Jersey: Slack, 1974: 35-62.

25 Solcia E, Capella C, Vassallo G. Endocrine cells of the stomach and pancreas in states of gastric hypersecretion. Rend Gastroenterol 1970; 2: 147-58.

26 Pearse AGE, Bussolati G. Immunofluorescence studies of the distribution of gastrin cells in different clinical states. Gut 1970; 11: 646-8.

27 Creutzfelt W, Creutzfeldt C, Arnold R. The gastrin producing cells under normal and pathological condition. Rend Gastroenterol 1975; 7: 93-109.

28 Sloan JM, Buchanan KD, McFarland RJ, Titterinton P; Sanford JC. A histological study of the effect of chronic gastritis on gastrin-cell distribution in human stomach. J Clin Pathol 1970; 32: 201-7.

29 Byrnes DJ, Lorn SK, Sircus W. The relationship between functioning parietal cell and gastrin cell masses in two groups of duodenal ulcer patients. Clin Sci Mol Med 1976; 50: 375-83.

30 Creutzfeldt W, Arnold R, Creutzfeldt C, et al. Mucosal gastrin concentration, molecular forms of gastrin, number and ultrastructure of G-cell in patients with duodenal ulcer. Gut 1976; 17: 745-54.

31 Malstrom J, Stadil F. Gastrin content and gastrin release. Studies on the antral content of gastrin and its release to serum during stimulation by food. Scand $J$ Gastroenterol 1976; Suppl 37: 71-6.

32 Harty RF, McGuigan JE. Effects of cyclic adenosine and cyclic guanosine nucleotides and theophylline on gastrin synthesis and secretin in rat antral organ cultures. Pharmacology 1982; 24: 35-44.

33 Saffouri B, Weir G, Bitar K, Mahklouf G. Stimulation 
of gastrin secretion from the perfused rat stomach by somatostatin antiserum. Life Sci 1979; 25: 1749-54.

34 Schusdziarra V, Zyznar E, Rouiller D, Boden G, Brown JC, Arimura A, Unger RH. Splanchnic somatostatin: a hormonal regulator of nutrient homeostasis. Science 1980; 207: 530-2.

35 Larsson LI, Goltermann N, Magistris L, Rehfeld JF, Schwart TW. Somatostatin cell processes as pathways for paracrine secretion. Science 1979; 205: 1393-5.
36 Saffouri B, Weir GC, Bitar KN, Mahklouf GM. Gastrin and somatostatin secretion by perfused rat stomach: functional linkage of antral peptides. $\mathrm{Am} \mathrm{J}$ Physiol 1980; 238: G495-G501.

37 Arnold R, Hülst MV, Neuhof $\mathrm{CH}$, Schwarting $\mathrm{H}$, Beaker HD, Creutzfeldt W. Antral gastrin-producing G-cells and somatostatin-producing D-cells in different states of gastric acid secretion. Gut 1982; 23: 285-91. 